\title{
Review Article \\ Recent Advances in the Pathogenesis of Syndromic Autisms
}

\author{
A. Benvenuto, B. Manzi, R. Alessandrelli, C. Galasso, and P. Curatolo \\ Pediatric Neurology Unit, Department of Neuroscience, “Tor Vergata” University of Rome, 00133 Rome, Italy \\ Correspondence should be addressed to P. Curatolo, curatolo@uniroma2.it
}

Received 10 December 2008; Accepted 13 May 2009

Recommended by Alan Richard Spitzer

Background. Current advances in genetic technology continue to expand the list of medical conditions associated with autism. Clinicians have to identify specific autistic-related syndromes, and to provide tailored counseling. The aim of this study is to elucidate recent advances in autism research that offer important clues into pathogenetic mechanisms of syndromic autism and relevant implications for clinical practice. Data Sources. The PubMed database was searched with the keywords "autism" and "chromosomal abnormalities," "metabolic diseases," "susceptibility loci." Results. Defined mutations, genetic syndromes, and metabolic diseases account for up to $20 \%$ of autistic patients. Metabolic and mitochondrial defects may have toxic effects on the brain cells, causing neuronal loss and altered modulation of neurotransmission systems. Alterations of the neocortical excitatory/inhibitory balance and perturbations of interneurons' development represent the most probable pathogenetic mechanisms underlying the autistic phenotype in Fragile X-Syndrome and Tuberous Sclerosis Complex. Chromosomal abnormalities and potential candidate genes are strongly implicated in the disruption of neural connections, brain growth, and synaptic/dendritic morphology. Conclusion. Metabolic testing may be appropriate if specific symptoms are present. Highresolution chromosome analysis may be recommended if a specific diagnosis is suspected because of obvious dysmorphisms. Identifying cryptic chromosomal abnormalities by whole genome microarray analysis can increase the understanding of the neurobiological pathways to autism.

Copyright () 2009 A. Benvenuto et al. This is an open access article distributed under the Creative Commons Attribution License, which permits unrestricted use, distribution, and reproduction in any medium, provided the original work is properly cited.

\section{Introduction}

Autism and related autism spectrum disorders (ASDs) are heterogeneous neurodevelopmental disorders behaviorally defined by significant deficits in social interaction and communication and by the presence of restricted interests and repetitive behaviors [1]. Autism Disorder (AD) comorbidy with seizures and mental retardation occurs in up to $30 \%$ and in $80 \%$ of autistic patients, respectively [2]. Its pathogenetic substrates are still largely unknown. Despite strong familial components, clinical complexity has posed a major challenge to our understanding of autism pathogenesis. Genetically, the picture is complicated by significant interindividual heterogeneity, numerous contributing loci, and multiple genes and gene-environment interactions [3]. Several lines of evidences strongly support a prenatal onset for developmental abnormalities later leading to autism [4]. Autism in its very broad spectrum of severity is known to have many different etiologies. In the last few years, significant progresses have been made in comprehending the causes of autism, and their multiple impacts on the developing brain [5]. The primary goals of treatment are optimizing the quality of life and minimizing the impairment due to the core symptoms of autism [6].

In this article we discuss current understanding of the pathogenesis of syndromic autism and the multiple pathways responsible for the ASD phenotype.

\section{Metabolic Diseases}

Several inborn errors of metabolism, including phenylketonuria, biotinidase deficiency, disorders of cerebrospinal fluid (CSF) neurotransmitters such as deficiencies of folic acid, Smith-Lemli-Opitz syndrome (SLOS), creatine deficiency syndromes, metabolic purine disorders, have an autistic phenotype [7]. A better understanding of some of them has implications both for discovery of the pathophysiologic underpinnings of the disorder and for the development of effective interventions. 
In untreated children affected by phenylketonuria, the high levels of phenylalanine may have toxic effects on the brain cells, causing reduction of myelin, neuronal loss, and decreased levels of interneuronal connections [8]. Hyperphenylalaninemia also competes with the absorbition of other amino acids and consequently lower tyrosine and tryptophan concentrations can result in a low production of dopamine and serotonin in the prefrontal cortex [9].

In some of the most severe metabolic diseases, like adenylosuccinase deficiency or creatine deficiency syndromes, neurological and behavioral symptoms are probably not caused by deficiency of metabolites, but are more likely due to the toxic effects of the accumulating substances on the brain [8]. A direct role in modulation of dopaminergic and serotoninergic neurotransmission systems and axonal guidance has been hypothesized for the adenosine deaminase deficiency as pathologic mechanisms for the development of altered pathways involved in autistic symptoms [10]. The role of mitochondrial disorders has been revitalized by the association between autism and variants of the SLC25A12 gene, which encodes the predominant isoform of the mitochondrial aspartate (asp)/glutamate (glu) carrier (AGC) in brain [11]. Altered $\mathrm{Ca} 2+$ homeostasis is responsible for boosting AGC activity, mitochondrial metabolism, and, to a more variable degree, oxidative stress in autistic brains [12]. Based on our clinical experience, routine metabolic screening studies should be used on a case by-case basis, in the presence of the autistic regression, or suggestive clinical findings, such as lethargy, cyclic vomiting, early onset seizures, dysmorphic features, mental retardation with neurologic deficits, unexplained immune deficiency or unexplained hemolytic anemia, hyper- or hypotonia, self-mutilation, and muscle weakness [13]. Table 1 summarizes the main clinical features, diagnostic test and therapeutic options of the metabolic diseases most frequently associated with ASD.

\section{Epilepsy and Regressive Autism}

The relationship among epilepsy, autism, and regression is a poorly understood and controversial subject. There are several epilepsy syndromes in which regression of language, cognition, and behavior may lead to clinical manifestations that overlap with the behavioral syndrome of autism, such as infantile spasms, slow spike-wave discharges during sleep, and focal centrotemporal spikes. An epileptic disorder must be considered in all children with a low functioning ASD, especially when a history of regression and electroencephalogram (EEG) epileptic abnormalities is present [14]. Severe epileptiform abnormalities may permanently alter the critical synaptogenesis by strengthening synaptic contacts that should have been naturally pruned [15]. Cognitive functions decline in those patients who have early-onset EEG abnormalities and a prolonged active phase of continuous spike-and-wave discharges during sleep [16]. In children with autistic regression, there is no evidence that treatment of the seizures or of the interictal epileptiform activity makes a difference in regard to the outcome of the language and social deficits. Because the relationship between autism, epilepsy, and regression is complex, the clinician's index of suspicion for epilepsy should be high, and treatment of the epilepsy should be pursued when necessary.

Although the pathogenetic link between autism and epilepsy is poorly understood, the existence of altered $\mathrm{Ca} 2+$ signaling in ASD and the bioelectrical instability resulting from mutations of the L-type voltage-gated Ca2+ channels associated to autism may account for the high prevalence of seizures and/or EEG abnormalities present among autistic individuals [17].

\section{Genetic Diseases Associated with Autism}

Single gene defects and chromosomal abnormalities may account for approximately up to $10 \%$ [18] of individuals with autism, and the fraction is likely to be higher when microarray comparative genome hybridization is used [19]. Table 2 summarizes the most frequent genetic syndromes and cytogenetic abnormalities associated with autism.

4.1. Fragile X Syndrome. Abnormalities in long-term synaptic plasticity of excitatory synapses and in baseline synaptic connectivity may be the underlying neurological substrate of autism associated with FXS [20,21]. Alterations in the neocortical excitatory/inhibitory balance as well as abnormal neural synchronization have been also reported in mouse model of FXS [22], resulting in hyperexcitability of neocortical circuits. An immature dendritic morphology may also increase susceptibility to epilepsy and anxiety in FXS patients [23].

4.2. Tuberous Sclerosis Complex. Tuberous sclerosis complex (TSC) is an inherited disorder resulting from mutations in one of two genes, TSC1 (Hamartin) and TSC2 (Tuberin), characterized by benign hamartomatous tumors that involve multiple organ systems. It is commonly associated with neuropsychiatric complications like epilepsy, mental retardation, autism, and other behavioral problems. Seizures can be present in the first year of life and up to one third of children develop infantile spasms. Neurobehavioral phenotypes in TSC may arise from perturbations of interneurons development, which can selectively impact frontal and parietal areas [24]. TSC2 gene localized on 16p13.3 locus encodes for tuberin, a protein highly expressed in frontal regions [25]. Furthermore, several studies have described the TSC 1 locus 9q34 as an important region of vulnerability for the developmental of autism. A loss of a single TSC1 gene copy in mice is sufficient to perturb cytoskeletal dynamics and dendritic spine structure, highlighting generalized neurotrophic roles for these genes, in addition to cell growth regulation. Circuitry alterations are the possible biological substrate of autism associated with TSC.

\section{Chromosomal Abnormalities}

A wide number of cytogenetic abnormalities have been described [26], particularly in the low functioning autistic population with dysmorphic features [27]. 
TABLE 1: Diagnosis and potential therapeutic approaches in some metabolic diseases associated with autism.

\begin{tabular}{|c|c|c|c|c|c|}
\hline Metabolic diseases & $\begin{array}{l}\text { Potential patogenetic } \\
\text { mechanisms }\end{array}$ & Clinical features & Diagnosis & $\begin{array}{l}\text { Therapetic } \\
\text { options }\end{array}$ & Refs \\
\hline Phenylketonuria & $\begin{array}{l}\text { Low production of } \\
\text { dopamine and } \\
\text { serotonin. Toxic } \\
\text { effects on the brain } \\
\text { cells. Reduction of } \\
\text { myelin. }\end{array}$ & $\begin{array}{l}\text { Neonatal onset Autism, seizures, } \\
\text { severe mental retardation, } \\
\text { hyperactivity, EEG abnormalities } \\
\text { and seizures, microcephaly, } \\
\text { albinism (excessively fair hair and } \\
\text { skin) or a tendency to } \\
\text { hypopigmentation and eczema, } \\
\text { "musty or mousy" odor of skin, } \\
\text { hair, sweat, and urine. }\end{array}$ & $\begin{array}{l}\text { Quantitative plasma } \\
\text { amino acids analysis. } \\
\text { Dosage of } \\
\text { phenylpyruvic acid in } \\
\text { urine. }\end{array}$ & $\begin{array}{l}\text { Restricted diet }+ \\
\text { aminoacids } \\
\text { administration. }\end{array}$ & {$[28,29]$} \\
\hline $\begin{array}{l}\text { Adenylosuccinase } \\
\text { deficit }\end{array}$ & $\begin{array}{l}\text { Toxic effects of the } \\
\text { accumulating succinyl } \\
\text { purines on the brain. }\end{array}$ & $\begin{array}{l}\text { Onset in the first year. Autistic } \\
\text { phenotype, profound psychomotor } \\
\text { retardation, epilepsy, hypotonia, } \\
\text { peripheral hypertonia, failure to } \\
\text { thrive. No dismorphic features. }\end{array}$ & $\begin{array}{l}\text { Succinyl } \\
\text { aminoimidazole, } \\
\text { carboxamide riboside } \\
\text { and succinyl } \\
\text { adenosine in urine } \\
\text { and cerebrospinal } \\
\text { fluid. }\end{array}$ & $\begin{array}{l}\text { Therapy with } \\
\text { D-ribose. }\end{array}$ & {$[7,30]$} \\
\hline $\begin{array}{l}\text { Smith-Lemli-Opitz } \\
\text { syndrome }\end{array}$ & $\begin{array}{l}\text { Neurosteroid } \\
\text { deficiency. Alteration } \\
\text { of neuroendocrine } \\
\text { functions and } \\
\text { disruption of the } \\
\text { growth and } \\
\text { development of many } \\
\text { body systems. }\end{array}$ & $\begin{array}{l}\text { Onset in infancy. Autism, mental } \\
\text { retardation, sensory hyperreactivity, } \\
\text { irritability, language impairment, } \\
\text { sleep cycle disturbance, } \\
\text { self-injurious behavior, } \\
\text { microchepaly, hypotonia, } \\
\text { syndactyly, hypogenitalism, } \\
\text { malformations of the brain, lung, } \\
\text { heart, and gastrointestinal tract. }\end{array}$ & $\begin{array}{l}\text { Abnormal sterol } \\
\text { pattern (low plasma } \\
\text { and tissue cholesterol } \\
\text { concentrations, and } \\
\text { increased plasma and } \\
\text { tissue } \\
7 \text {-dehydrocholesterol } \\
\text { reductase and its } \\
\text { metabolite). }\end{array}$ & $\begin{array}{l}\text { Cholesterol } \\
\text { replacement } \\
\text { therapy. }\end{array}$ & {$[31,32]$} \\
\hline $\begin{array}{l}\text { Creatine deficiency } \\
\text { syndromes }\end{array}$ & $\begin{array}{l}\text { Neurotoxic effect of } \\
\text { guanidinoacetate or } \\
\text { other guanidine } \\
\text { compounds. }\end{array}$ & $\begin{array}{l}\text { Autistic phenotype, mental } \\
\text { retardation, speech delay, epilepsy, } \\
\text { extrapyramidal symptoms, } \\
\text { progressive encephalopathy with } \\
\text { muscular hypotonia, dyskinetic } \\
\text { movements, developmental } \\
\text { arrest/regression. }\end{array}$ & $\begin{array}{l}\text { Blood and urinary } \\
\text { concentration on } \\
\text { creatine and } \\
\text { guanidinoacetate, } \\
\text { Brain magnetic } \\
\text { resonance } \\
\text { spectroscopy. }\end{array}$ & $\begin{array}{l}\text { Oral creatine } \\
\text { supplementa- } \\
\text { tion. Restriction } \\
\text { of arginine and } \\
\text { substitution of } \\
\text { ornithine. }\end{array}$ & {$[33]$} \\
\hline
\end{tabular}

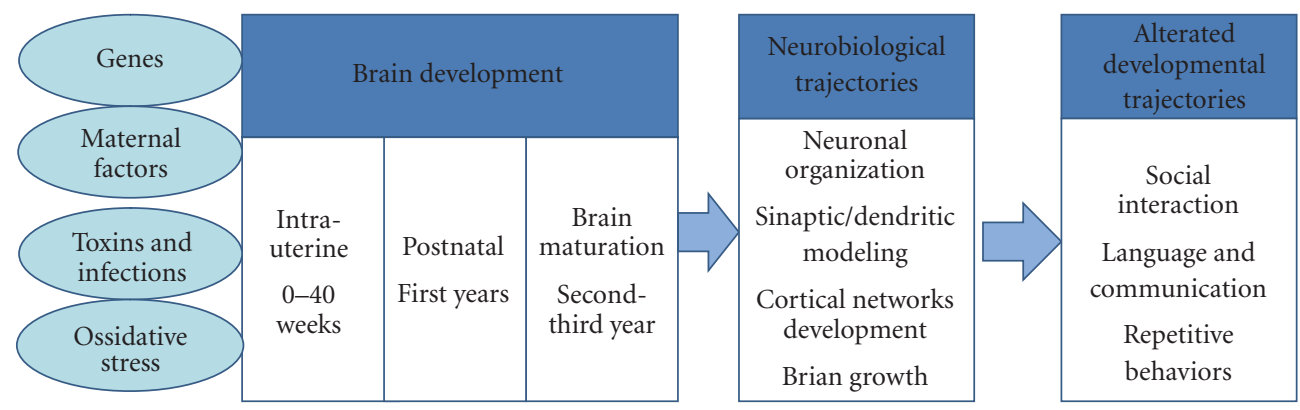

FIGURE 1: Genetic and epigenetic factors involved in the pathogenesis of autism. Interactions between multiple genes and environmental factors, such as intrauterine infections, alcohol/toxins exposure, and obstetrical suboptimality, can influence intrauterine and early postnatal brain development and disrupt crucial neurobiological pathways, from neuronal migration and cortical organization to synaptic and dendritic conformation, resulting in alterations of neurobehavioral trajectories that are involved in the pathogenesis of ASD.

5.1. Chromosome 15. Chromosomal rearrangements in $15 q 11-15 q 13$ region might be the most frequent cytogenetic abnormality in ASD [34], accounting for 1-2\% of patients. A chromosome 15 phenotype II , characterized by ataxia, language delay, epilepsy, mental retardation, repetitive movement disorders, and facial dysmorphic features, has been described in individuals with chromosome 15 duplications [35]. Within the 15q11-15q13 locus, gamma-aminobutyric acid A receptor beta 3 (GABRB3), an inhibitory neurotransmitter receptor, are currently thought to be central likely to play a significant role in the development of ASD, due to its role in the neuronal inhibition and its expression in early 


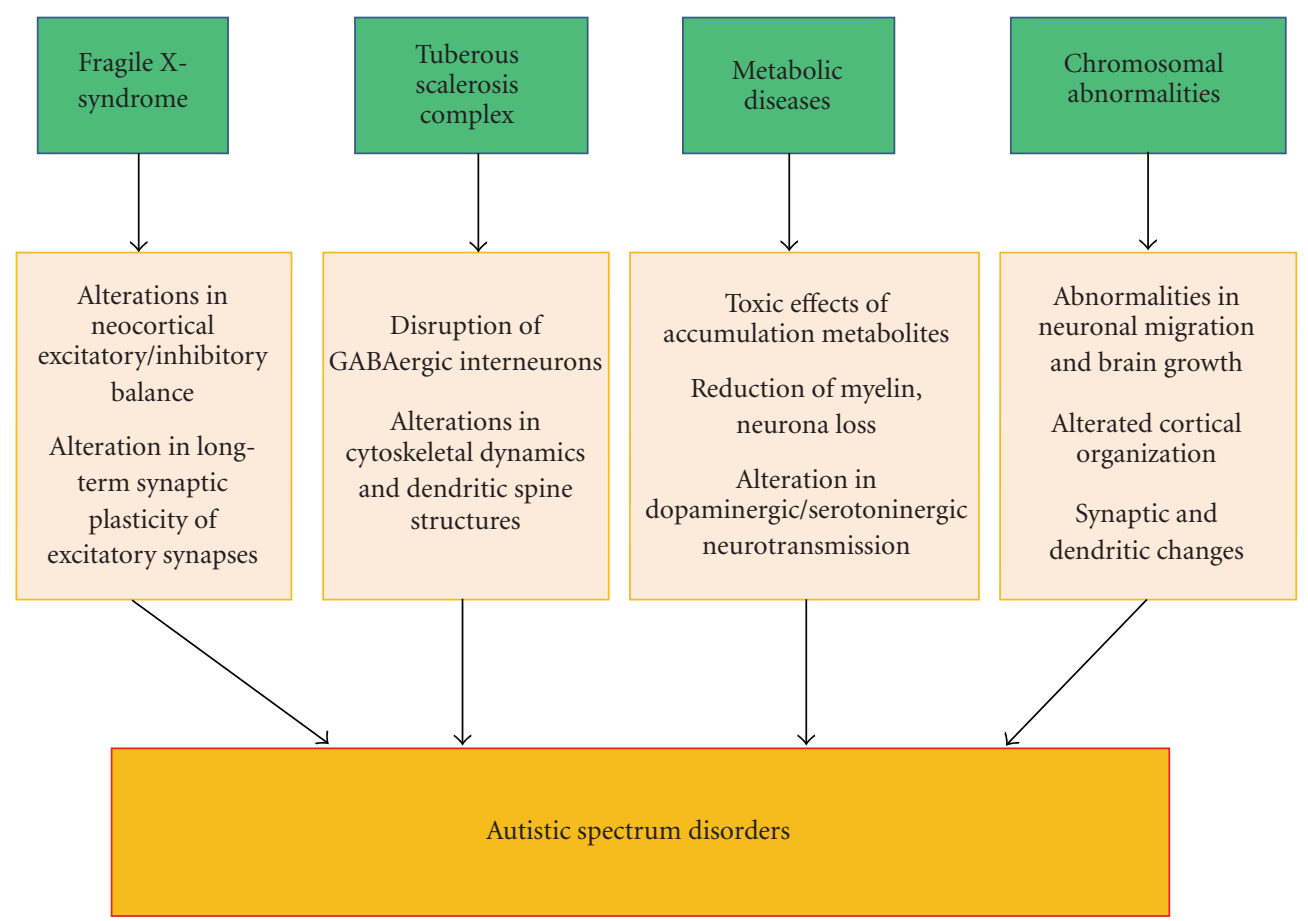

Figure 2: Potential pathogenetic mechanisms of syndromic autism. Several medical conditions associated with syndromic autism appear to influence and potentially disrupt neurodevelopmental processes, including brain growth, cortical connectivity, and neurotransmitters pathways. These neurobiological alterations likely affect the developmental trajectory of social behavior and communication during early stages of childhood and determine the different clinical phenotypes of ASD.

development [36]. This finding is particularly interesting in light of the high incidence of seizures and EEG abnormalities in autistic patients.

5.2. Chromosome 7. Two of the loci most commonly associated with ASD by genetic linkage studies $[37,38](7 \mathrm{q} 22$ and $7 \mathrm{q} 31$ regions) contain several genes implicated in the pathogenesis of autism. The RELN gene, found within the $7 \mathrm{q} 22$ region, has a pivotal role in neuronal migration and prenatal development of neural connections, [39, 40] and is potently inhibited by toxic substances, such as organophosphates [41].

Increased risk for autism can be also linked to a functional polymorphism in the MET gene, found within the $7 \mathrm{q} 31$ locus [42], which plays a role into development of the cerebral cortex and cerebellum. The Williams-Beuren syndrome (WBS) region (7q11.23) also contains several genes associated with impairment in language and social interaction [43-45], suggesting the existence of a specific subgroup of autistic patients, characterized by dysmorphic features, mental retardation, language delay, congenital heart disease, and hypersensitivity to sound.

5.3. Chromosome 16. An association between a larger microdeletion on 16p11.2 and a syndrome that included developmental delay and distinct facial appearance (hypertelorism, a broad nasal bridge and a broad nasal tip with a prominent columella, a short philtrum, long ears, a large mouth) has been described [46-48]. The chromosomal region 16p11.2 also encompasses the PRKCB1 locus, an interesting gene previously found associated with autism [49], and expressed in the CNS, the immune system, the digestive tract, and the kidney. A recent study has described an association between PRKCB1 and an enhanced urinary peptide excretion rate [50].

5.4. Chromosome 2. Deletions involving $2 \mathrm{q} 37$ have been observed in more than 70 individuals with autism, mental retardation, and dysmorphic features (prominent forehead, depressed nasal bridge, dysmorphic ears and nose, short stature, and short hands and feet) $[51,52]$. Three different breakpoints of $2 \mathrm{q} 37(2 \mathrm{q} 37.1,2 \mathrm{q} 37.2,2 \mathrm{q} 37.3)$ have been analyzed to clarify the genotype-phenotype relationships associated with different terminal deletions [53], and several candidate genes for autism have been identified in $2 \mathrm{q} 37.3$ band [54]. Furthermore, a correlation between autism and a de novo cryptic deletion of chromosome 2p25.2 has been described [55]. The interaction between potential candidate genes that are expressed on these loci may explain the phenotypical heterogeneity and the spectrum of neuropsychological deficits associated with 2q37 and 2p25.2 deletion syndromes.

Other regions implicated in the ASDs with possible candidate genes are summarizes in Table 3.

\section{Pathogenetic Pathways}

Several molecular pathways potentially involved in the disruption of neurodevelopmental trajectories during intrauterine or postnatal brain development may be associated 
TABLE 2: Genetic syndromes associated with autism.

\begin{tabular}{|c|c|c|c|c|c|}
\hline Syndrome & $\begin{array}{l}\text { Gene(s) } \\
\text { associated } \\
\text { with the } \\
\text { syndrome }\end{array}$ & $\begin{array}{l}\text { Proportion of } \\
\text { patients with an } \\
\text { ASD that have the } \\
\text { syndrome }\end{array}$ & $\begin{array}{l}\text { Proportion of } \\
\text { patients with the } \\
\text { syndrome that } \\
\text { have an ASD }\end{array}$ & Clinical signs & Refs \\
\hline $\begin{array}{l}\text { Fragile-X } \\
\text { syndrome }\end{array}$ & FMR1 & $2-5 \%$ & $20-40 \%$ & $\begin{array}{l}\text { Mental retardation, long face with prominent } \\
\text { ears, macroorchidism, social anxiety, sensory } \\
\text { hypersensitivity, stereotypies, poor motor } \\
\text { coordination, delayed speech development. }\end{array}$ & {$[56,57]$} \\
\hline $\begin{array}{l}\text { Tuberous } \\
\text { sclerosis }\end{array}$ & $\begin{array}{l}\text { TSC1, } \\
\text { TSC2 }\end{array}$ & $3-4 \%$ & $43-86 \%$ & $\begin{array}{l}\text { Epilepsy, mental retardation, specific learning } \\
\text { disabilities, ADHD disorder, autistic spectrum } \\
\text { disorders. }\end{array}$ & {$[58,59]$} \\
\hline $\begin{array}{l}\text { 15q duplication } \\
\text { Angelman/Prader } \\
\text { Will syndrome }\end{array}$ & $\begin{array}{l}\text { UBE3A } \\
\text { GABAr } \\
\text { cluster }\end{array}$ & $1-2 \%$ & $>40 \%$ & $\begin{array}{l}\text { Ataxia, language delay, epilepsy, mental } \\
\text { retardation, repetitive movements, } \\
\text { obsessive-compulsive symptoms. }\end{array}$ & {$[60]$} \\
\hline 16p11 deletion & PCKB1 & $1 \%$ & High & $\begin{array}{l}\text { Developmental delay, distinct facial appearance, } \\
\text { autism. }\end{array}$ & {$[46,61]$} \\
\hline 22q deletion & SHANK3 & $1 \%$ & High & $\begin{array}{l}\text { Speech and language disability, social } \\
\text { impairment. }\end{array}$ & {$[62,63]$} \\
\hline 2q37 deletion & $\begin{array}{l}\text { KIF1A, } \\
\text { GBX2 }\end{array}$ & Unknown & $50 \%$ & $\begin{array}{l}\text { Developmental delay, mental retardation, } \\
\text { hypotonia, hyperactivity, autistic traits, } \\
\text { dysmorphic features (cleft palate, temporal bone } \\
\text { abnormalities, hypoplastic lungs). }\end{array}$ & {$[64]$} \\
\hline Joubert syndrome & AHI1 & Unknown & $40 \%$ & $\begin{array}{l}\text { Partial/complete agenesis of the cerebellar } \\
\text { vermis, ataxia, abnormalities of ocular } \\
\text { movements, cognitive, and behavioral } \\
\text { dysfunction. }\end{array}$ & {$[65]$} \\
\hline $\begin{array}{l}\text { Timothy } \\
\text { syndrome }\end{array}$ & CACNA1C & Unknown & $60-70 \%$ & $\begin{array}{l}\text { Cardiac arrhythmia, long QT syndrome, mental } \\
\text { retardation, and ASD. }\end{array}$ & {$[66]$} \\
\hline $\begin{array}{l}\text { Cortical } \\
\text { dysplasia-focal } \\
\text { epilepsy } \\
\text { syndrome }\end{array}$ & CNTNAP2 & Rare & $70 \%$ & Seizures and language regression. & {$[67,68]$} \\
\hline
\end{tabular}

with abnormal developmental processes, from neuronal migration and cortical organization to synaptic and dendritic conformation [69]. Furthermore, environmental factors, including maternal/intrauterine infections, exposure to toxins, and ossidative stress, may modify the underlying genetic substrate and leading to abnormalities in neuronal organization and cortical network development [70]. Figure 1 summarizes both genetic background and epigenetic factors involved in the pathogenesis of ASD, and explains how their multifactorial influence may be necessary for full expression of the autistic phenotype. Defined medical syndromes, chromosomal abnormalities and de novo copy number variations (CNVs) may account for $10 \%$ of ASD cases [71]. Figure 2 illustrates many different types of potential pathogenetic mechanisms responsible for the ASD phenotype in the most common medical conditions associated with autism. Widespread genetic testing would be expensive, time-consuming, and generally inappropriate due to the etiological complexity, while the appropriate use of genetic testing in subgroups of autistic patients showing particular clinical features is relevant to good clinical practice and may allow the identifications of new susceptibility variants. The advent of fluorescent in situ hybridization (FISH) techniques has expanded the list of chromosomal hot spots in autism. Individual FISH studies may be indicated in the confirmation of a clinically suspected condition [72], and in the evaluation of low functioning patients with an IQ $<50$ [73]. When dysmorphic features are present, it is reasonable to suspect chromosomal rearrangements even if the karyotype appears normal, and oligo-array-based CGH analysis is highly advisable in these cases [74]. Whole genomescanning by array-based technology has detected copynumber variations (CNVs), which are copy-number changes involving a DNA fragment, and represent submicroscopic deletions or duplications that are undetectable at the routine cytogenetic analysis [75-78]. In conclusion, as etiologies of ASD are progressively discovered, the number of individuals with idiopathic autism will progressively shrink. The role of the neuropediatrician will be to understand the neurological basis of autism, and to identify more homogenous subgroups with specific biologic markers. Because autism represents an extremely heterogeneous group of disorders, a better 
TABLe 3: Candidate genes associated with autism.

\begin{tabular}{|c|c|c|c|c|c|c|}
\hline Genes & Chromosomes & Proteins & Proteins' functions & $\begin{array}{l}\text { Neurobiological } \\
\text { abnormalities }\end{array}$ & Clinical phenotypes & Refs \\
\hline $\begin{array}{l}\text { NGL3 } \\
\text { NGL4 }\end{array}$ & $\begin{array}{l}X q 13.1 \\
\text { Xp22.3 }\end{array}$ & $\begin{array}{l}\text { Neuroligin } \\
3 / 4 \text {. }\end{array}$ & $\begin{array}{l}\text { Synaptic } \\
\text { transmission, } \\
\text { differentiation of } \\
\text { synaptic contacts. }\end{array}$ & $\begin{array}{l}\text { Synaptic or dendritic } \\
\text { changes. }\end{array}$ & $\begin{array}{l}\text { Autism with motor tics, Mild to } \\
\text { severe autism, PDD-NOS, } \\
\text { "regression" at disease onset, with a } \\
\text { loss of initially-acquired social and } \\
\text { verbal milestones, no dysmorphic } \\
\text { features. }\end{array}$ & {$[79,80]$} \\
\hline SHANK3 & $22 \mathrm{q} 13$ & $\begin{array}{l}\text { Shank } \\
\text { scaffolding } \\
\text { proteins. }\end{array}$ & $\begin{array}{l}\text { Master organizer of } \\
\text { postsynaptic } \\
\text { glutamatergic density. }\end{array}$ & $\begin{array}{l}\text { Synaptic or dendritic } \\
\text { changes. }\end{array}$ & $\begin{array}{l}\text { Multiple developmental delays, } \\
\text { dysmorphic features, autism with } \\
\text { severe language/social deficits. }\end{array}$ & {$[81,82]$} \\
\hline MET/HGF & $7 q 31$ & $\begin{array}{l}\text { MET recep- } \\
\text { tortyrosine } \\
\text { kinase/ } \\
\text { hepatocyte } \\
\text { growth } \\
\text { factor. }\end{array}$ & $\begin{array}{l}\text { Regulation of } \\
\text { dendritic morphology } \\
\text { and promoting } \\
\text { neurite outgrowth. }\end{array}$ & $\begin{array}{l}\text { Abnormalities in } \\
\text { development of the } \\
\text { cerebral cortex and } \\
\text { cerebellum. }\end{array}$ & $\begin{array}{l}\text { Autism, increased anxiety, seizures, } \\
\text { immune, and gastrointestinal } \\
\text { problems. }\end{array}$ & {$[83]$} \\
\hline MECP2 & $\mathrm{Xq} 28$ & $\begin{array}{l}\text { Methyl-CpG- } \\
\text { binding } \\
\text { protein } 2 .\end{array}$ & $\begin{array}{l}\text { Synapse maintenance } \\
\text { and remodeling. }\end{array}$ & $\begin{array}{l}\text { Synaptic or dendritic } \\
\text { changes. }\end{array}$ & $\begin{array}{l}\text { Rett syndrome with regression, } \\
\text { mental retardation, microcephaly, } \\
\text { stereotyped behaviors, epilepsy and } \\
\text { breathing problems; verbal Rett } \\
\text { variants. }\end{array}$ & {$[84]$} \\
\hline HOXA1 & $7 \mathrm{p} 15.3$ & $\begin{array}{l}\text { Homeobox } \\
\text { protein. }\end{array}$ & $\begin{array}{l}\text { Regulation of brain } \\
\text { growth. }\end{array}$ & $\begin{array}{l}\text { Abnormalities of } \\
\text { numbers of neurons } \\
\text { or glia in the brain. }\end{array}$ & $\begin{array}{l}\text { Mental retardation, autism and } \\
\text { distinct clinical features (horizontal } \\
\text { gaze abnormalities, focal weakness, } \\
\text { hypoventilation, vascular } \\
\text { malformations). }\end{array}$ & {$[85]$} \\
\hline PTEN & $10 q 23$ & $\begin{array}{l}\text { phosphatase } \\
\text { and tensin } \\
\text { homologue. }\end{array}$ & $\begin{array}{l}\text { Regulation of cells } \\
\text { proliferation/ } \\
\text { differentiation. }\end{array}$ & $\begin{array}{l}\text { Abnormalities in } \\
\text { brain growth. }\end{array}$ & $\begin{array}{l}\text { Macrocephaly, macrosomia, autism } \\
\text { and developmental delay, increased } \\
\text { risk of developing a variety of } \\
\text { PTEN-related cancers in adulthood. }\end{array}$ & {$[86,87]$} \\
\hline
\end{tabular}

understanding of underlying biological processes will lead to more targeted intervention approaches that can be designed for specific subtypes of autism.

\section{Acknowledgments}

Arianna Benvenuto (medical doctor) drew the first draft with the assistance and contribution of Barbara Manzi (Medical Doctor). Riccardo Alessandrelli (Medical Doctor) reviewed relevant articles on the literature under the supervision of Cinzia Galasso (Associated Professor of the Department of Pediatric Neuroscience Unit) on genetic aspects. Professor Paolo Curatolo (Director of the Department of Pediatric Neuroscience Unit) proposed and designed the study, revised the final draft and is the guarantor. All authors contribute to the intellectual contents and approve the final version.

\section{References}

[1] American Psychiatric Association, Diagnostic and Statistical Manual of Mental Disorders, American Psychiatric Association, Washington, DC, USA, 3rd edition, 1994.

[2] T. P. Berney, "Autism—an evolving concept," British Journal of Psychiatry, vol. 176, pp. 20-25, 2000.
[3] A. M. Persico and T. Bourgeron, "Searching for ways out of the autism maze: genetic, epigenetic and environmental clues," Trends in Neurosciences, vol. 29, no. 7, pp. 349-358, 2006.

[4] M. T. Miller, K. Strömland, L. Ventura, M. Johansson, J. M. Bandim, and C. Gillberg, "Autism associated with conditions characterized by developmental errors in early embryogenesis: a mini review," International Journal of Developmental Neuroscience, vol. 23, no. 2-3, pp. 201-219, 2005.

[5] A. Benvenuto, R. Moavero, R. Alessandrelli, B. Manzi, and P. Curatolo, "Syndromic autism: causes and pathogenetic pathways," World Journal of Pediatrics. In press.

[6] S. M. Myers, C. P. Johnson, P. H. Lipkin, et al., "Management of children with autism spectrum disorders," Pediatrics, vol. 120, no. 5, pp. 1162-1182, 2007.

[7] B. Manzi, A. L. Loizzo, G. Giana Grazia, and P. Curatolo, "Autism and metabolic diseases," Journal of Child Neurology, vol. 23, no. 3, pp. 307-314, 2008.

[8] P. R. Huttenlocher, "The neuropathology of phenylketonuria: human and animal studies," European Journal of Pediatrics, vol. 159, no. 2, pp. S102-S106, 2000.

[9] A. Diamond, "Evidence for the importance of dopamine for prefrontal cortex functions early in life," Philosophical Transactions of the Royal Society B, vol. 351, no. 1346, pp. 1483-1494, 1996.

[10] M. Okada, Y. Kawata, T. Murakami, K. Wada, K. Mizuno, and S. Kaneko, "Interaction between purinoceptor subtypes 
on hippocampal serotonergic transmission using in vivo microdialysis," Neuropharmacology, vol. 38 , no. 5, pp. 707715, 1999.

[11] R. Segurado, J. Conroy, E. Meally, M. Fitzgerald, M. Gill, and L. Gallagher, "Confirmation of association between autism and the mitochondrial aspartate/glutamate carrier SLC25A12 gene on chromosome 2q31," American Journal of Psychiatry, vol. 162, no. 11, pp. 2182-2184, 2005.

[12] L. Palmieri, V. Papaleo, V. Porcelli, et al., "Altered calcium homeostasis in autism-spectrum disorders: evidence from biochemical and genetic studies of the mitochondrial aspartate/glutamate carrier AGC1," Molecular Psychiatry. In press.

[13] M. A. Kayser, "Inherited metabolic diseases in neurodevelopmental and neurobehavioral disorders," Seminars in Pediatric Neurology, vol. 15, no. 3, pp. 127-131, 2008.

[14] R. Canitano, "Epilepsy in autism spectrum disorders," European Child and Adolescent Psychiatry, vol. 16, no. 1, pp. 61-66, 2007.

[15] G. L. Holmes, "Influence of brain development on status epilepticus," Epilepsia, vol. 48, supplement 8, pp. 19-20, 2007.

[16] M. C. Smith and T. J. Hoeppner, "Epileptic encephalopathy of late childhood: Landau-Kleffner syndrome and the syndrome of continuous spikes and waves during slow-wave sleep," Journal of Clinical Neurophysiology, vol. 20, no. 6, pp. 462-472, 2003.

[17] J. F. Krey and R. E. Dolmetsch, "Molecular mechanisms of autism: a possible role for $\mathrm{Ca}^{2+}$ signaling," Current Opinion in Neurobiology, vol. 17, no. 1, pp. 112-119, 2007.

[18] G. E. Herman, N. Henninger, K. Ratliff-Schaub, M. Pastore, S. Fitzgerald, and K. L. McBride, "Genetic testing in autism: how much is enough?” Genetics in Medicine, vol. 9, no. 5, pp. 268-274, 2007.

[19] J. Sebat, B. Lakshmi, D. Malhotra, et al., "Strong association of de novo copy number mutations with autism," Science, vol. 316, no. 5823, pp. 445-449, 2007.

[20] I. Bureau, G. M. G. Shepherd, and K. Svoboda, "Circuit and plasticity defects in the developing somatosensory cortex of Fmr1 knock-out mice," Journal of Neuroscience, vol. 28, no. 20, pp. 5178-5188, 2008.

[21] L. Selby, C. Zhang, and Q.-Q. Sun, "Major defects in neocortical GABAergic inhibitory circuits in mice lacking the fragile X mental retardation protein," Neuroscience Letters, vol. 412, no. 3, pp. 227-232, 2007.

[22] J. R. Gibson, A. F. Bartley, S. A. Hays, and K. M. Huber, "Imbalance of neocortical excitation and inhibition and altered UP states reflect network hyperexcitability in the mouse model of fragile X syndrome," Journal of Neurophysiology, vol. 100, no. 5, pp. 2615-2626, 2008.

[23] J. Pickett and E. London, "The neuropathology of autism: a review," Journal of Neuropathology and Experimental Neurology, vol. 64, no. 11, pp. 925-935, 2005.

[24] V. Napolioni, R. Moavero, and P. Curatolo, "Recent advances in neurobiology of tuberous sclerosis complex," Brain and Development, vol. 31, no. 2, pp. 104-113, 2009.

[25] S. F. Tavazoie, V. A. Alvarez, D. A. Ridenour, D. J. Kwiatkowski, and B. L. Sabatini, "Regulation of neuronal morphology and function by the tumor suppressors Tsc1 and Tsc2," Nature Neuroscience, vol. 8, no. 12, pp. 1727-1734, 2005.

[26] J. A. S. Vorstman, W. G. Staal, E. Van Daalen, H. Van Engeland, P. F. R. Hochstenbach, and L. Franke, "Identification of novel autism candidate regions through analysis of reported cytogenetic abnormalities associated with autism," Molecular Psychiatry, vol. 11, no. 1, pp. 18-28, 2006.
[27] C. R. Marshall, A. Noor, J. B. Vincent, et al., "Structural variation of chromosomes in autism spectrum disorder," American Journal of Human Genetics, vol. 82, no. 2, pp. 477488, 2008.

[28] S. Baieli, L. Pavone, C. Meli, A. Fiumara, and M. Coleman, "Autism and phenylketonuria," Journal of Autism and Developmental Disorders, vol. 33, no. 2, pp. 201-204, 2003.

[29] T. L. Lowe, K. Tanaka, and M. Seashore, "Detection of phenylketonuria in autistic and psychotic children," Journal of the American Medical Association, vol. 243, no. 2, pp. 126-128, 1980.

[30] F. Ciardo, C. Salerno, and P. Curatolo, "Neurologic aspects of adenylosuccinate lyase deficiency," Journal of Child Neurology, vol. 16, no. 5, pp. 301-308, 2001.

[31] D. M. Sikora, K. Pettit-Kekel, J. Penfield, L. S. Merkens, and R. D. Steiner, "The near universal presence of autism spectrum disorders in children with Smith-Lemli-Opitz syndrome," American Journal of Medical Genetics Part A, vol. 140, no. 14, pp. 1511-1518, 2006.

[32] P. E. Jira, R. A. Wevers, J. de Jong, et al., "Simvastatin: a new therapeutic approach for Smith-Lemli-Opitz syndrome," Journal of Lipid Research, vol. 41, no. 8, pp. 1339-1346, 2000.

[33] A. Arias-Dimas, M. A. Vilaseca, R. Artuch Iriberri, A. Ribes, and J. Campistol, "Diagnosis and treatment of brain creatine deficiency syndromes," Revista de Neurologia, vol. 43, no. 5, pp. 302-308, 2006.

[34] E. M. Dykens, J. S. Sutcliffe, and P. Levitt, "Autism and 15Q11Q13 disorders: behavioral, genetic, and pathophysiological issues," Mental Retardation and Developmental Disabilities Research Reviews, vol. 10, no. 4, pp. 284-291, 2004.

[35] Y. Shao, M. L. Cuccaro, E. R. Hauser, et al., "Fine mapping of autistic disorder to chromosome 15q11-q13 by use of phenotypic subtypes," American Journal of Human Genetics, vol. 72, no. 3, pp. 539-548, 2003.

[36] D. Q. Ma, P. L. Whitehead, M. M. Menold, et al., "Identification of significant association and gene-gene interaction of GABA receptor subunit genes in autism," American Journal of Human Genetics, vol. 77, no. 3, pp. 377-388, 2005.

[37] S. Palferman, N. Matthews, M. Turner, et al., "Further characterization of the autism susceptibility locus AUTS1 on chromosome 7q," Human Molecular Genetics, vol. 10, no. 9, pp. 973-982, 2001.

[38] M. S. Yang and M. Gill, "A review of gene linkage, association and expression studies in autism and an assessment of convergent evidence," International Journal of Developmental Neuroscience, vol. 25, no. 2, pp. 69-85, 2007.

[39] S. E. Hong, Y. Y. Shugart, D. T. Huang, et al., "Autosomal recessive lissencephaly with cerebellar hypoplasia is associated with human RELN mutations," Nature Genetics, vol. 26, no. 1, pp. 93-96, 2000.

[40] S. H. Fatemi, A. V. Snow, J. M. Stary, et al., "Reelin signaling is impaired in autism," Biological Psychiatry, vol. 57, no. 7, pp. 777-787, 2005.

[41] C. C. Quattrocchi, F. Wannenes, A. M. Persico, et al., "Reelin is a serine protease of the extracellular matrix," The Journal of Biological Chemistry, vol. 277, no. 1, pp. 303-309, 2002.

[42] D. B. Campbell, J. S. Sutcliffe, P. J. Ebert, et al., "A genetic variant that disrupts MET transcription is associated with autism," Proceedings of the National Academy of Sciences of the United States of America, vol. 103, no. 45, pp. 16834-16839, 2006.

[43] A. Meyer-Lindenberg, C. B. Mervis, and K. Faith Berman, "Neural mechanisms in Williams syndrome: a unique window 
to genetic influences on cognition and behaviour," Nature Reviews Neuroscience, vol. 7, no. 5, pp. 380-393, 2006.

[44] M. Kirchhoff, A.-M. Bisgaard, T. Bryndorf, and T. Gerdes, "MLPA analysis for a panel of syndromes with mental retardation reveals imbalances in $5.8 \%$ of patients with mental retardation and dysmorphic features, including duplications of the Sotos syndrome and Williams-Beuren syndrome regions," European Journal of Medical Genetics, vol. 50, no. 1, pp. 33-42, 2007.

[45] L. Edelmann, A. Prosnitz, S. Pardo, et al., "An atypical deletion of the Williams-Beuren syndrome interval implicates genes associated with defective visuospatial processing and autism," Journal of Medical Genetics, vol. 44, no. 2, pp. 136-143, 2007.

[46] L. A. Weiss, Y. Shen, J. M. Korn, et al., "Association between microdeletion and microduplication at 16p11.2 and autism," The New England Journal of Medicine, vol. 358, no. 7, pp. 667675, 2008.

[47] B. C. Ballif, S. A. Hornor, E. Jenkins, et al., "Discovery of a previously unrecognized microdeletion syndrome of 16p11.2p12.2," Nature Genetics, vol. 39, no. 9, pp. 1071-1073, 2007.

[48] P. Finelli, F. Natacci, M. T. Bonati, et al., "FISH characterisation of an identical (16)(p11.2p12.2) tandem duplication in two unrelated patients with autistic behaviour," Journal of Medical Genetics, vol. 41, no. 7, p. e90, 2004.

[49] A. Philippi, E. Roschmann, F. Tores, et al., "Haplotypes in the gene encoding protein kinase c-beta (PRKCB1) on chromosome 16 are associated with autism," Molecular Psychiatry, vol. 10, no. 10, pp. 950-960, 2005.

[50] C. Lintas, R. Sacco, K. Garbett, et al., "Involvement of the PRKCB1 gene in autistic disorder: significant genetic association and reduced neocortical gene expression," Molecular Psychiatry, pp. 1-14, 2008.

[51] K. A. Casas, T. K. Mononen, C. N. Mikail, et al., "Chromosome $2 \mathrm{q}$ terminal deletion: report of 6 new patients and review of phenotype-breakpoint correlations in 66 individuals," American Journal of Medical Genetics Part A, vol. 130, no. 4, pp. 331-339, 2004.

[52] J. L. Gorski, B. A. Cox, M. Kyine, W. Uhlmann, and T. W. Glover, "Terminal deletion of the long arm of chromosome 2 in a mildly dysmorphic hypotonic infant with karyotype 46,XY,del(2)(q37)," American Journal of Medical Genetics, vol. 32, no. 3, pp. 350-352, 1989.

[53] C. Galasso, A. Lo-Castro, C. Lalli, A. M. Nardone, F. Gullotta, and P. Curatolo, "Deletion 2q37: an identifiable clinical syndrome with mental retardation and autism," Journal of Child Neurology, vol. 23, no. 7, pp. 802-806, 2008.

[54] T. H. Wassink, J. Piven, V. J. Vieland, et al., "Evaluation of the chromosome 2q37.3 Gene CENTG2 as an autism susceptibility gene," American Journal of Medical Genetics Part $B$, vol. 136, no. 1, pp. 36-44, 2005.

[55] A. Lo-Castro, G. Giana, M. Fichera, et al., "Deletion 2p25.2: a cryptic chromosome abnormality in a patient with autism and mental retardation detected using aCGH," European Journal of Medical Genetics, vol. 52, no. 1, pp. 67-70, 2009.

[56] W. E. Kaufmann, R. Cortell, A. S. M. Kau, et al., "Autism spectrum disorder in fragile $\mathrm{X}$ syndrome: communication, social interaction, and specific behaviors," American Journal of Medical Genetics Part A, vol. 129, no. 3, pp. 225-234, 2004.

[57] R. J. Hagerman, M. Y. Ono, and P. J. Hagerman, "Recent advances in fragile $\mathrm{X}$ : a model for autism and neurodegeneration," Current Opinion in Psychiatry, vol. 18, no. 5, pp. 490496, 2005.
[58] S. E. Folstein and B. Rosen-Sheidley, "Genetics of autism: complex etiology for a heterogeneous disorder," Nature Reviews Genetics, vol. 2, pp. 943-955, 2001.

[59] P. Curatolo, M. C. Porfirio, B. Manzi, and S. Seri, "Autism in tuberous sclerosis," European Journal of Paediatric Neurology, vol. 8, no. 6, pp. 327-332, 2004.

[60] E. M. Dykens, J. S. Sutcliffe, and P. Levitt, "Autism and 15Q11Q13 disorders: behavioral, genetic, and pathophysiological issues," Mental Retardation and Developmental Disabilities Research Reviews, vol. 10, no. 4, pp. 284-291, 2004.

[61] R. A. Kumar, S. Karamohamed, J. Sudi, et al., "Recurrent 16 p11.2 microdeletions in autism," Human Molecular Genetics, vol. 17, no. 4, pp. 628-638, 2008.

[62] M. A. Manning, S. B. Cassidy, C. Clericuzio, et al., "Terminal 22q deletion syndrome: a newly recognized cause of speech and language disability in the autism spectrum," Pediatrics, vol. 114, no. 2, pp. 451-457, 2004.

[63] N. M. Mukaddes and S. Herguner, "Autistic disorder and 22q11.2 duplication," World Journal of Biological Psychiatry, vol. 8, no. 2, pp. 127-130, 2007.

[64] T. Lukusa, J. R. Vermeesch, M. Holvoet, J. P. Fryns, and K. Devriendt, "Deletion 2q37.3 and autism: molecular cytogenetic mapping of the candidate region for autistic disorder," Genetic Counseling, vol. 15, no. 3, pp. 293-301, 2004.

[65] A. I. Alvarez Retuerto, R. M. Cantor, J. G. Gleeson, et al., "Association of common variants in the Joubert syndrome gene (AHI1) with autism," Human Molecular Genetics, vol. 17, no. 24, pp. 3887-3896, 2008.

[66] I. Splawski, et al., "Ca (V) 1.2 calcium channel dysfunction causes a multisystem disorder including arrhythmia and autism," Cell, vol. 119, pp. 19-31, 2004.

[67] K. A. Strauss, E. G. Puffenberger, M. J. Huentelman, et al., "Recessive symptomatic focal epilepsy and mutant contactinassociated protein-like 2," The New England Journal of Medicine, vol. 354, no. 13, pp. 1370-1377, 2006.

[68] M. Alarcón, B. S. Abrahams, J. L. Stone, et al., "Linkage, association, and gene-expression analyses identify CNTNAP2 as an autism-susceptibility gene," American Journal of Human Genetics, vol. 82, no. 1, pp. 150-159, 2008.

[69] M. L. Bauman and T. L. Kemper, "Neuroanatomic observations of the brain in autism: a review and future directions," International Journal of Developmental Neuroscience, vol. 23, no. 2-3, pp. 183-187, 2005.

[70] C. A. Pardo and C. G. Eberhart, "The neurobiology of autism," Brain Pathology, vol. 17, no. 4, pp. 434-447, 2007.

[71] B. S. Abrahams and D. H. Geschwind, "Advances in autism genetics: on the threshold of a new neurobiology," Nature Reviews Genetics, vol. 9, no. 5, pp. 341-355, 2008.

[72] A. Battaglia and M. C. Bonaglia, "The yield of subtelomeric FISH analysis in the evaluation of autistic spectrum disorders," American Journal of Medical Genetics Part C, vol. 142, no. 1, pp. 8-12, 2006.

[73] G. B. Schaefer and N. J. Mendelsohn, "Genetics evaluation for the etiologic diagnosis of autism spectrum disorders," Genetics in Medicine, vol. 10, no. 1, pp. 4-12, 2008.

[74] C. Lintas and A. M. Persico, "Autistic phenotypes and genetic testing: state-of-the-art for the clinical geneticist," Journal of Medical Genetics, vol. 46, no. 1, pp. 1-8, 2009.

[75] S. L. Christian, C. W. Brune, J. Sudi, et al., "Novel submicroscopic chromosomal abnormalities detected in autism spectrum disorder," Biological Psychiatry, vol. 63, no. 12, pp. 1111-1117, 2008. 
[76] J. Sebat, B. Lakshmi, D. Malhotra, et al., "Strong association of de novo copy number mutations with autism," Science, vol. 316, no. 5823, pp. 445-449, 2007.

[77] C. R. Marshall, A. Noor, J. B. Vincent, et al., "Structural variation of chromosomes in autism spectrum disorder," American Journal of Human Genetics, vol. 82, no. 2, pp. 477488, 2008.

[78] P. Szatmari, A. D. Paterson, L. Zwaigenbaum, et al., "Mapping autism risk loci using genetic linkage and chromosomal rearrangements," Nature Genetics, vol. 39, no. 3, pp. 319-328, 2007.

[79] A. Lawson-Yuen, J.-S. Saldivar, S. Sommer, and J. Picker, "Familial deletion within NLGN4 associated with autism and Tourette syndrome," European Journal of Human Genetics, vol. 16, no. 5, pp. 614-618, 2008.

[80] J. Yan, G. Oliveira, A. Coutinho, et al., "Analysis of the neuroligin 3 and 4 genes in autism and other neuropsychiatric patients," Molecular Psychiatry, vol. 10, no. 4, pp. 329-332, 2005.

[81] R. Moessner, C. R. Marshall, J. S. Sutcliffe, et al., "Contribution of SHANK3 mutations to autism spectrum disorder," American Journal of Human Genetics, vol. 81, no. 6, pp. 1289-1297, 2007.

[82] C. M. Durand, C. Betancur, T. M. Boeckers, et al., "Mutations in the gene encoding the synaptic scaffolding protein SHANK3 are associated with autism spectrum disorders," Nature Genetics, vol. 39, no. 1, pp. 25-27, 2007.

[83] P. Levitt and D. B. Campbell, "The genetic and neurobiologic compass points toward common signaling dysfunctions in autism spectrum disorders," The Journal of Clinical Investigation, vol. 119, no. 4, pp. 747-754, 2009.

[84] M. Zappella, I. Meloni, I. Longo, et al., "Study of MECP2 gene in Rett syndrome variants and autistic girls," American Journal of Medical Genetics Part B, vol. 119, no. 1, pp. 102-107, 2003.

[85] T. M. Bosley, M. A. Salih, I. A. Alorainy, et al., "Clinical characterization of the HOXA1 syndrome BSAS variant," Neurology, vol. 69, no. 12, pp. 1245-1253, 2007.

[86] J. D. Buxbaum, G. Cai, P. Chaste, et al., "Mutation screening of the PTEN gene in patients with autism spectrum disorders and macrocephaly," American Journal of Medical Genetics Part $B$, vol. 144, no. 4, pp. 484-491, 2007.

[87] G. E. Herman, E. Butter, B. Enrile, M. Pastore, T. W. Prior, and A. Sommer, "Increasing knowledge of PTEN germline mutations: two additional patients with autism and macrocephaly," American Journal of Medical Genetics Part A, vol. 143, no. 6, pp. 589-593, 2007. 


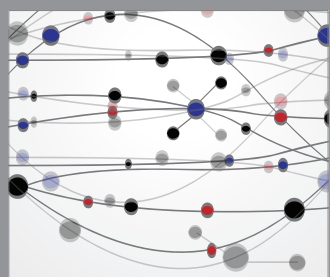

The Scientific World Journal
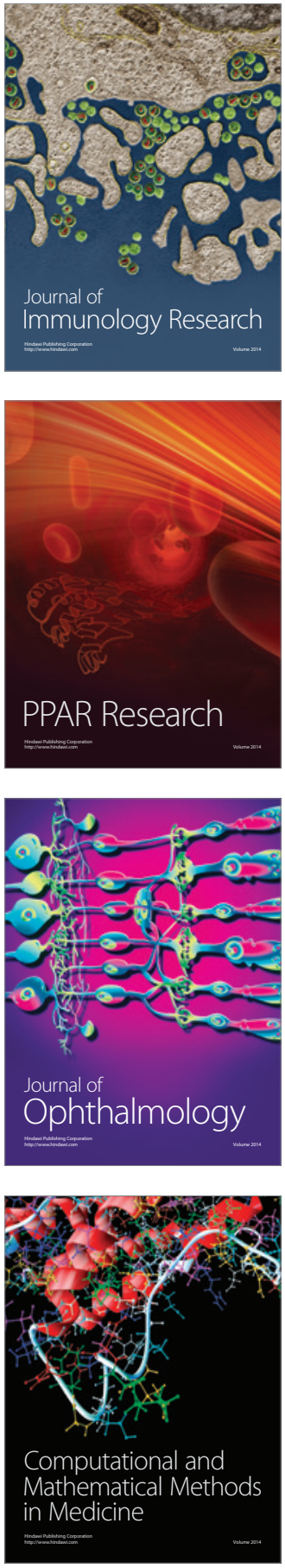

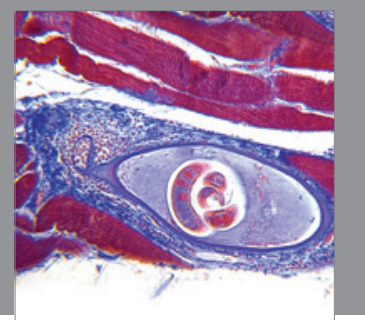

Gastroenterology

Research and Practice
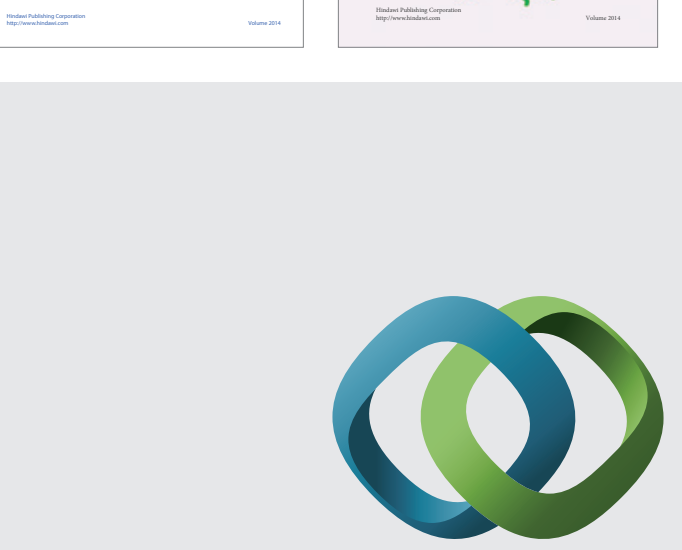

\section{Hindawi}

Submit your manuscripts at

http://www.hindawi.com
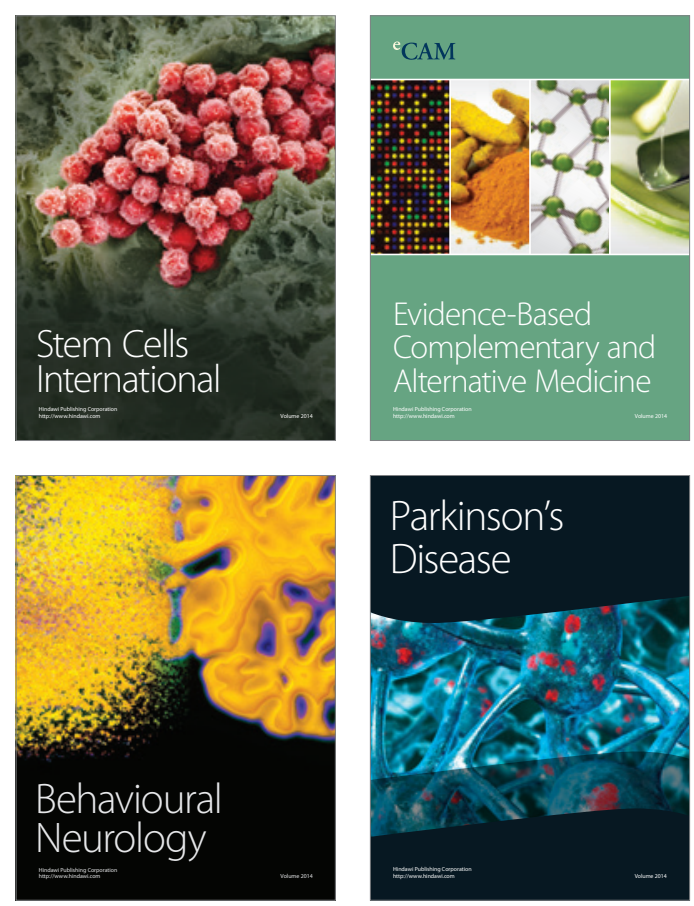

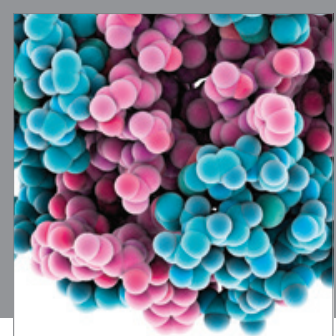

Journal of
Diabetes Research

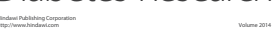

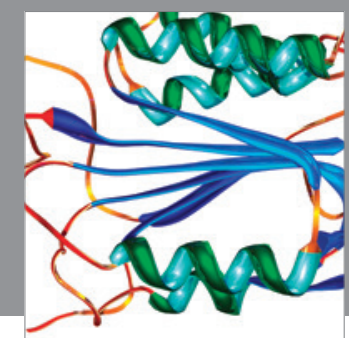

Disease Markers
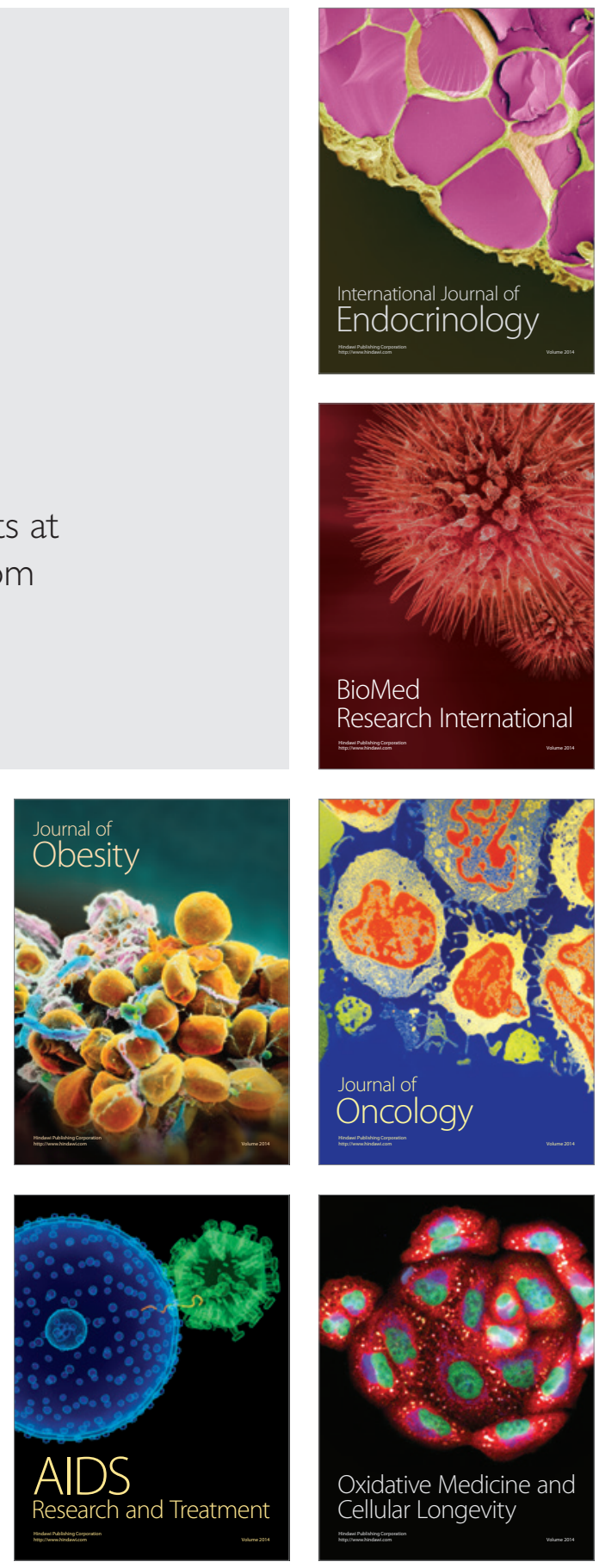